\title{
小型高性能力覚センサを用いたロールツーロールスパッタ装置用
} 張力計測システムの試作*

近藤 真也 ${ }^{* 1} \cdot$ 玉置 肇*1 . 竹中 宏*2
武村 守*3 . 小川 倉一 $* 4$

\section{Experimental Fabrication of Tension Measurement System for Roll-to-roll Sputtering Systems Using Highly Efficient Micro-sized Force Sensor}

\author{
Shinya KONDO*1, Hajime TAMAKI*1, Hiroshi TAKENAKA*2, \\ Mamoru TAKEMURA*3 and Soichi OGAWA*4 \\ *1Asahi Electronics Laboratory Co., Ltd., 1-4-16 Kawara-machi, Chuo-ku, Osaka 541-0048, Japan \\ ${ }^{*}$ Nippon Liniax Co., Ltd., 3-2 Sugahara-cho, Kita-ku, Osaka 530-0046, Japan \\ *3Technology Research Institute of Osaka Prefecture, 2-7-1 Ayumino, Izumi, Osaka 594-1157, Japan \\ ${ }^{* 4}$ Ogawa Creation Research Laboratory, 7-18-7 Kariguchi-dai, Tarumi-ku, Kobe, 655-0049, Japan
}

(Received November 6, 2010, Accepted February 5, 2011)

\begin{abstract}
Highly efficient micro-sized force sensor by using chromium silicon carbide ( $\mathrm{Cr}-\mathrm{Si}-\mathrm{C})$ composite thin film has been developed. The characteristic of the tension measurement system by using this force sensor for tension control as "Sensor roll", for roll-to-roll sputtering system is also described. Sensor roll can speed up the response to tension changes for 0.5 seconds than that of electromagnetic transformer type tension sensor. Sensor roll has been installed in roll-to-roll sputtering system and the behavior of the film has been observed, Sensor roll has enabled measuring in real time transient changes in tension. The tension measurement system with highefficiency and high-stability has been prepared in a vacuum environment by using the highly efficient micro-sized force sensor.
\end{abstract}

\section{1. はじめに}

フィルムベースエレクトロニクスの基盤技術のひとつとし て, 真空系ロールツーロールスパッタシステムが利用される が1,2), フィルム材料がより薄く高機能化すると, 搬送にお けるしわ・たわみの発生リスクが高くなるため, 張力制御を 高精度化することが重要視されている. 現在主に利用される 張力制御システムは, 張力検出器（ピローユニット）をロー ルに外付けし, 張力で押し下げられたロールの変位を差動変 圧器や電磁変圧器で間接的に検出するが, ピローユニットが 大きく設置場所が限定されており, 高温·真空環境下で, プ ラズマ放電の影響やアウトガス対策を考慮した利用が難しい ため, ロールッーロールスパッタシステムに対して高精度な 張力制御を適用することが困難であった.

前年度われわれは, スパッタ装置の高温・真空環境でも安 定した張力計測及び制御が可能となるシステムの開発を目指 して, 広い温度領域で特性の再現性が高いクロムシリコン カーバイド $(\mathrm{Cr}-\mathrm{Si}-\mathrm{C})$ 系複合薄膜を用いた小型高性能力覚 センサを開発した ${ }^{3)}$. これを張力検出部としてロールシャフ トに内蔵し, 張力のリアルタイム制御を目的とした, ピロー ユニット不要の張力直接計測システム（センサロール）を試 作した．センサロールを大気中フィルム巻替装置抢よび真空 系ロールッーロールスパッタ装置に搭載してフィルム走行 .

$*$ 平成 22 年 11 月 4 日 第51回真空に関する連合講演会で発表

*1 侏アサヒ電子研究所（广541-0048 大阪市中央区瓦町 1-4-16）

*2 日本リニアックス侏（干530-0046 大阪市北区菅原町 3-2）

*3 大阪府立産業技術総合研究所 (二594-1157 大阪府和泉市あゆ 久野 2-7-1)

*4 小川創造技術研究所（二655-0049 神戸市垂水区狩口台 7-187)

Vol. 54, No. 3, 2011

$-(35)$

成膜テストを行い, 様々な条件における張力制御への適用性 を検証した結果について報告する。

\section{2. 実験方法}

\section{1 力覚センサの作製}

Fig. 1 (a)に, Cr-Si-C 系複合薄膜による力覚センサ3)の外 観を示す. $3 \mathrm{~mm} \times 5 \mathrm{~mm} \times 0.5 \mathrm{~mm}$ のステンレス（SUS316） 基板片面を鏡面研磨後, $\mathrm{SiO}_{2}$ 膜による絶縁処理を施し, $\mathrm{Cr}-$ $\mathrm{Si}-\mathrm{C}$ 系複合材料を高周波 $(\mathrm{RF})$ スパッタ法でパターン成膜 した。パターンは抵抗線長と線幅の比（アスペクト比）を 510 , 膜厚を $15 \mathrm{~nm}$ に設定し, 膜の安定化を図るため, 350 ${ }^{\circ} \mathrm{C} \cdot 12$ 時間のエイジング処理を行った ${ }^{3)}$.

\section{2 張力検出モジュールの作製}

応力伝達を考慮すると, ロールシャフトと検出部は一体ま たは剛結とすることが望ましいが，センサとシャフト全体を 一体構造とすると調整や保守作業がしにくくなり精度不安定 の原因ともなる．このため Fig. 1(b)に示すように，シャフ 卜両端を分離・剛結可能な構造とし, 両端部を力覚センサ内 蔵の張力検出モジュールとして構成した.

シャフト内のセンサ搭載位置は, センサ応答感度の高くな る剪断応力の影響が大きく, 他の成分 (主応力等) が干渉し ない場所とすることが望ましいため, ロールの 3 次元モデ ルを CAD で構築し, 力や拘束 (固定) 等境界条件を設定し て, 有限要素法 (Finite Elements Method, FEM) を用いた 応力解析により最適位置を決定した. この位置に対し応力集 中による感度向上を考慮して穴を空け, センサ挿入溝（幅 $3.2 \mathrm{~mm}$ ) を加工した. 力覚センサの側面 2 箇所に接合剤 (ThreeBond 社製一液性エポキシ配合樹脂2285) を塗布して 溝に挿入・固定し, 電気炉で $150^{\circ} \mathrm{C} \cdot 60$ 分間熱硬化させモジ 
(a)

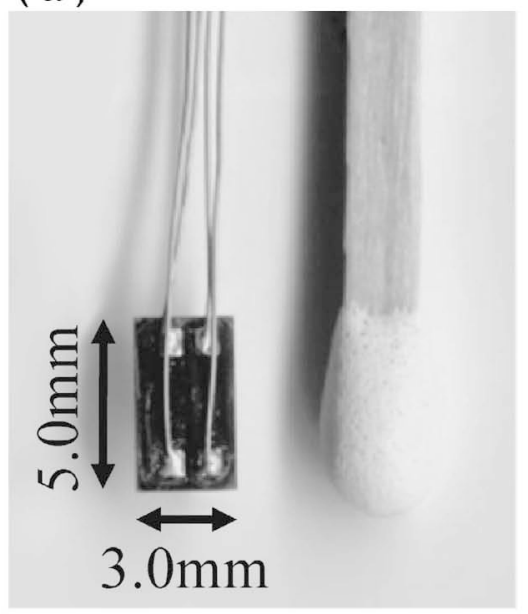

(b)

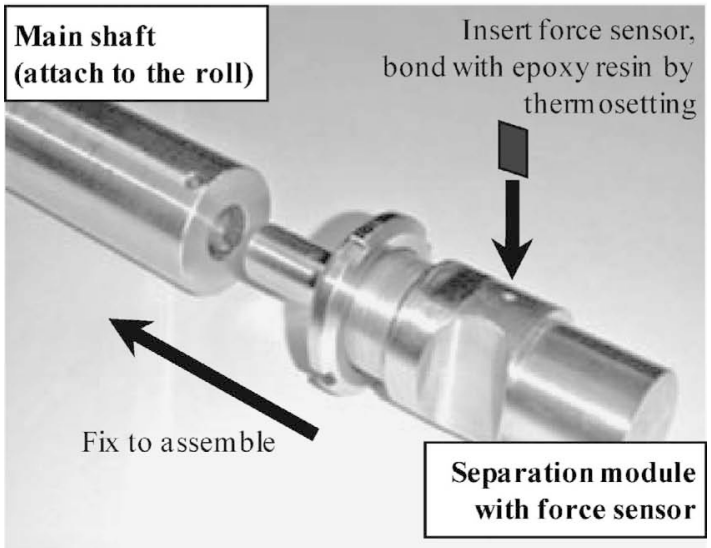

Fig. 1 The appearance of force sensor by $\mathrm{Cr}-\mathrm{Si}-\mathrm{C}$ composite thin film (a), and an example of separation module of roll shaft for tension measurement (b).

ュールを作製した．このとき，接合剤内の気泡による応力感 度の低下を防ぐため，直前に接合剂の擋挥脱泡処理を行った。

\section{3 ロールツーロールシステムによる動作テスト}

センサロールを搭載した大気中仕様のロールッーロールフ ィルム巻替装置の外観を Fig. 2(a) に, 張力計測部付近の搬 送経路の概要を Fig. 2(b)に示す. 経路中央のニップロール によって張力の及ぶ範囲を区切り, その直前・直後に電磁変 圧器型張力検出器, 巻取側付近に差動変圧器型張力検出器を 設置した，一方，力覚センサを内蔵したセンサロールは，巻 出側付近 (Fig. 2(b)中の $(\mathrm{A}))$ およびニップロール前後の電 磁変圧器型検出器に対応する位置（同 (B), (C) ) に配置し た. 張力の付与・制御は，巻出・巻取部それぞれに設置のダ ンサロール及びサーボモータの速度調整によって行った．装 置に幅 $500 \mathrm{~mm}$ のフィルムを渡し, 静止状態, 張力付与, 走 行開始, 停止, 張力開放の各動作について，センサロール信 号の経時変化を従来の張力検出器と同時に取得して比較検証 した.

ロールッーロールスパッタ装置の概略を Fig. 3 に示す. 搬送経路は記載部分を含む複数の真空槽で構成され，経路の 巻出・巻取部付近に設置した差動变圧器型張力検出器とモー タによって張力を付与・検出・制御している. 槽を高真空を

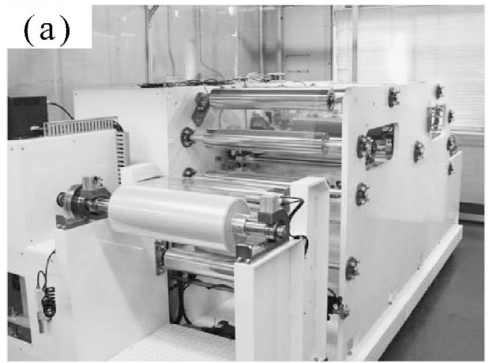

(b)

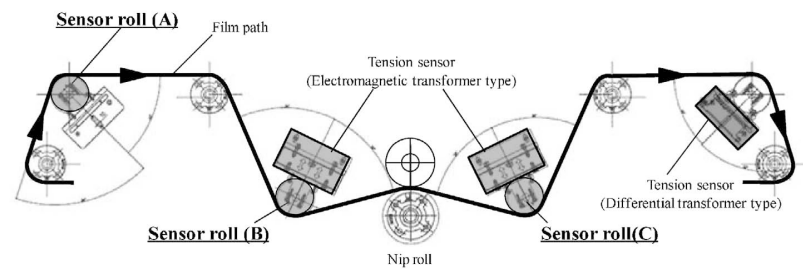

Fig. 2 Experimentally fabricated roll-to-roll film winding machine used in the atmosphere for polyethylene terephthalate film (a), and film path outline and sensor roll position of this machine (b).

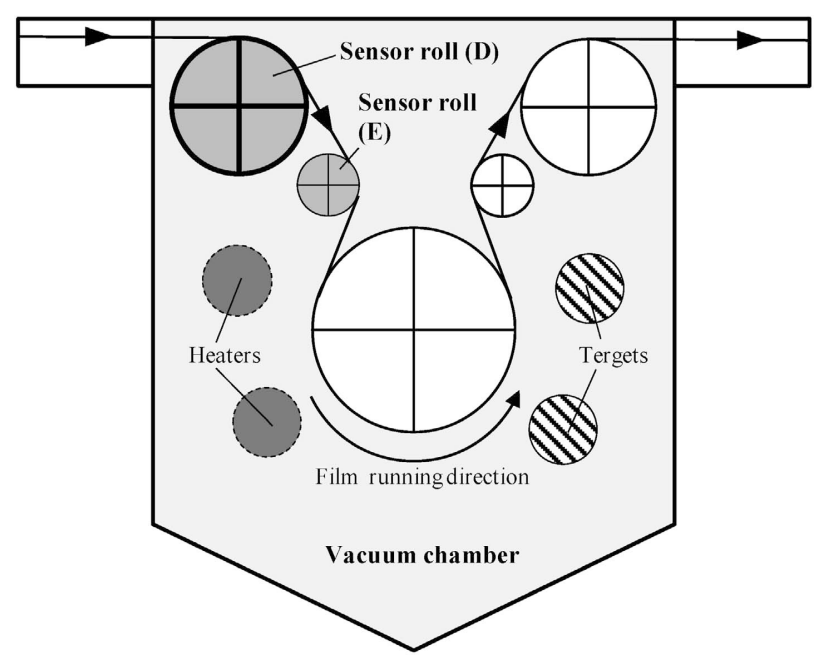

Fig. 3 Outline of the vacuum chamber of the roll-to-roll sputtering system for manufacturing conductive thin film.

で排気後, 槽内温度, 搬送速度, ターゲット等の異なるスパ ッタ成膜条件においてセンサロールが検出する張力の経時変 化データを取得し，槽内フィルムの張力変化について検証を 行った.

\section{3. 結果之検討}

\section{1 大気中フィルム巻替装置による走行テスト}

室温 $26^{\circ} \mathrm{C}$ の大気中に扔いて, フィルム巻替装置による一 連走行 (静止, 張力付与, 走行, 停止, 張力開放) を行った 際の検出信号の経時変化を Fig. 4 亿示す. 実線がセンサ ロール (Fig. 2(b) 中の (C)), 破線が同じ位置に設置の電磁 変圧器型張力検出器の信号, 一点鎖線はライン速度の実測值 である. 張力付与・開放時においては, センサロールの信号 変化は電磁変圧器型の傾向々一定の整合性が見られた。フィ ルム走行時, ダンサロール及びサーボモータの張力制御の影 
(In the atmosphere, temp. $26^{\circ} \mathrm{C}$ )

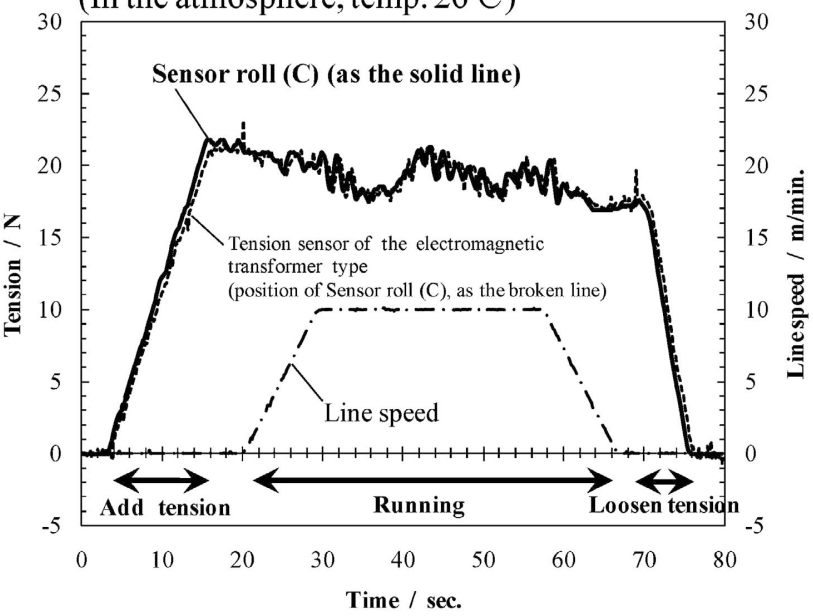

Fig. 4 Comparison of tension signals between Sensor roll (C) in Fig. 2(b) and electromagnetic transformer type tension sensor in an operation series of the film winding machine.

(a)

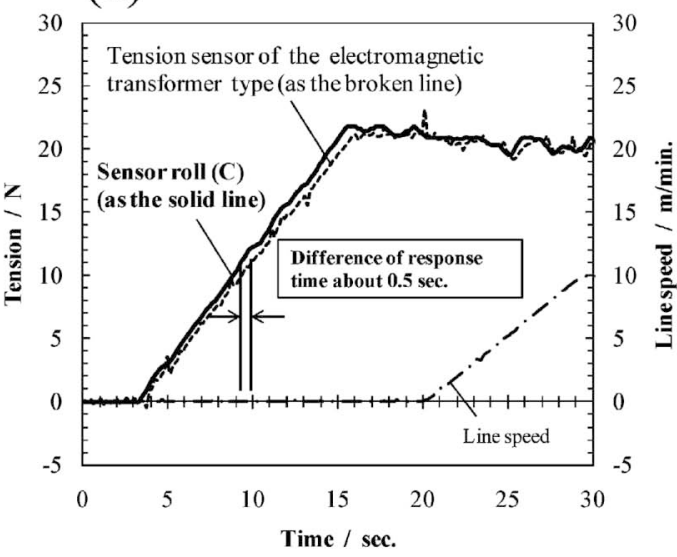

(b)

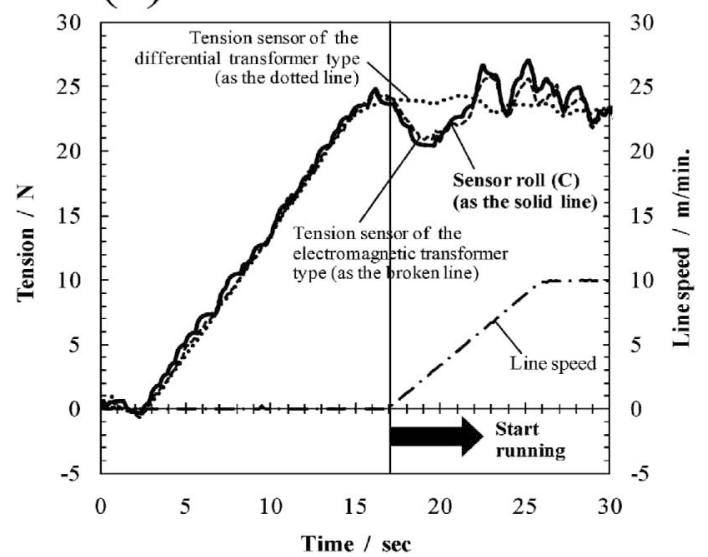

Fig. 5 Comparison of tension signals in the film winding machine operation, between electromagnetic transformer type tension sensor and Sensor roll (C) at the stretching period (a), among differential transformer type, electromagnetic transformer type and Sensor roll (C) at the stretching and transient period (b). (a) 1 st process (in the high vacuum chamber, temp. $100^{\circ} \mathrm{C}$ )

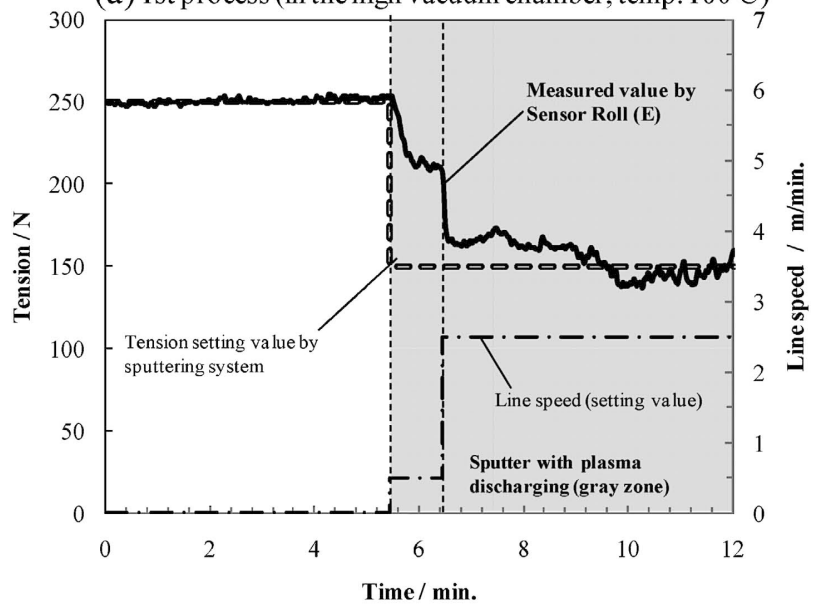

(b) 2 nd process (in the high vacuum chamber, temp. $90^{\circ} \mathrm{C}$ )

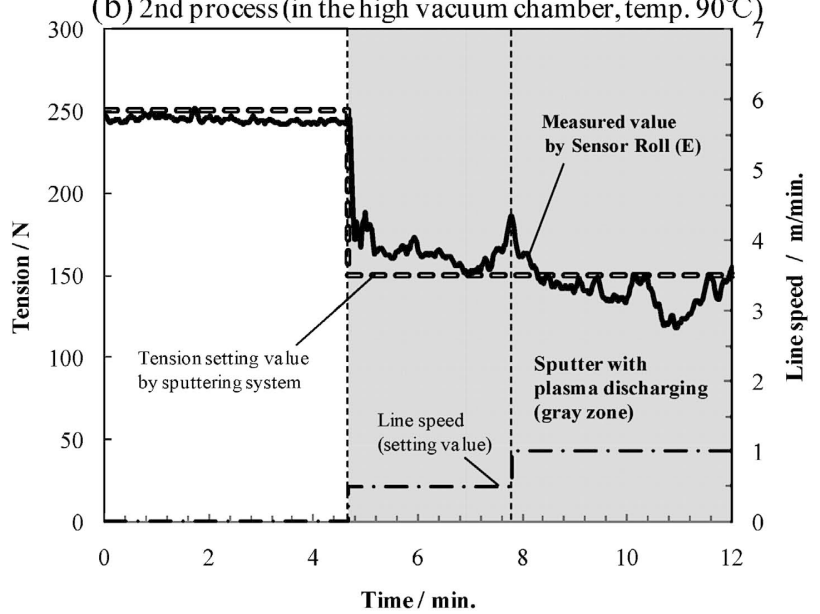

Fig. 7 Time transition data of tension measured by Sensor roll $(\mathrm{E})$ installed in the roll-to-roll sputtering system in two different sputtering conditions, the first process of film sputtering (a), the second process of film sputtering (b).

響により，張力值にはライン速度に応じた周期変動が生じる が, センサロールは電磁変圧器型とほぼ同じ周期変動を検出 していることが確認できた.

フィルムに張力を加える際の検出信号の時間応答性を比較 した. Fig. 5(a)は，Fig. 4の走行開始から安定走行にかけ ての変化を拡大したものであるが，センサロールが，張力の 付与に対し, 電磁変圧器型に比べて約 0.5 秒速い応答をして いることが確認できた.

フィルム静止状態から走行状態への移行時に張力変化が起 こった際の, センサロール (Fig. 2(b)中の $(\mathrm{C})$ ), 電磁変圧 器型検出器, 差動変圧器型検出器それぞれの張力検出值の比 較を Fig. 5(b)に示す. 実線がセンサロール, 破線が電磁変 圧器型 (センサロール $(\mathrm{C})$ の直下に設置), 点線が差動変圧 器型の張力信号, 一点鎖線がライン速度の実測值である. セ ンサロールと電磁変圧器型検出器の信号が張力の変化に追随 する一方で, 差動变圧器型検出器の信号は比較的平滑な推移 を示した. さらに走行状態において, 電磁変圧器型に比べ, センサロールの信号が張力変化に対してより大きなピークを 示していることを確認した. 


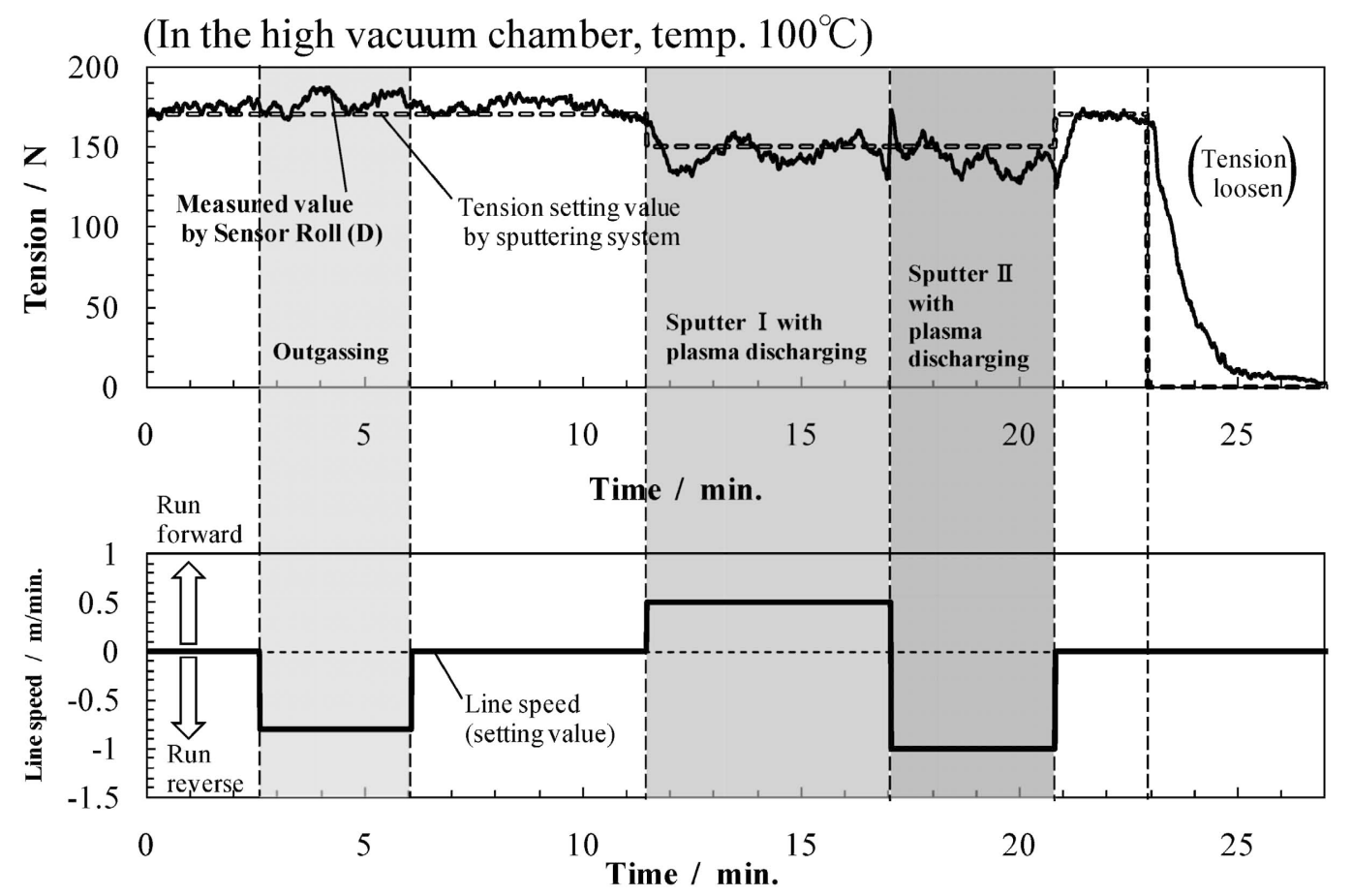

Fig. 6 Time transition data of tension measured by Sensor roll (D) (in Fig. 3) installed in the roll-to-roll sputtering system in operation of outgassing and sputtering processes.

\section{2 ロールツーロールスパッタ装置による成膜テスト}

センサロールを搭載したロールッーロールスパッタ装置を 使用し, 槽内温度 $100^{\circ} \mathrm{C}$ 高真空下に打いて脱ガス処理及び 2 種のスパッタ成膜を行った際のセンサロール（Fig. 3 中の (D)）信号の経時変化を Fig. 6 に示す．上グラフの実線は センサロール信号，破線は装置の張力設定値，下グラフはラ イン速度の設定值で，ライン速度の值が正の場合は Fig. 3 の矢印方向, 負の場合は逆方向にフィルムを搬送している.

センサロールの張力検出信号について, 脱ガス処理前後の温 度変化やスパッタ時のプラズマ放電による影響が若干見られ るものの, 設定值変更や張力開放に対する検出値の追随, 久 パッタ走行中のライン速度に応じた張力の周期変化など, 真 空・高温環境下においても大気中と同様なフィルム張力変化 を確認することができた。

槽内温度・搬送速度の異なるスパッタ条件に抢いて, セン サロールにより張力検出を行いデータを比較した. Fig. 7

(a) は 1 次, Fig. 7(b)は 2 次のスパッタ工程に打けるセン サロール (Fig. 3 中の $(\mathrm{E})$ ) の張力検出データ (実線) で, 破線は装置の張力設定値, 一点鎖線はライン速度の設定值で ある. 各工程はそれぞれターゲット・搬送速度・槽内温度の 条件が異なっている。いずれの条件においても環境に左右さ れることなく, 張力が設定值へ安定するまで過渡的に変化す る状況を確認することができた，センサロールによりスパッ 夕装置内のフィルム張力を十分計測・制御できる可能性が見 出された。

\section{4. まとめ}

$\mathrm{Cr}-\mathrm{Si}-\mathrm{C}$ 系複合薄膜を用いて作製した小型高性能力覚セン サを，ロールッーロール装置のシャフトへ内蔵したセンサ
ロールについて, 様々な環境で張力検出器としての適用性の 検証を行い，次のような成果が得られた。

1）張力変化に対する応答時間を, 電磁変圧器型張力検 出器に比べ約 0.5 秒高速化することができた.

2) 走行開始直後の過渡的領域に打いて, 差動変圧器型 張力検出器で計測困難であった張力変化を検出できた.

3） 真空中に加え, $100^{\circ} \mathrm{C}$ 以上の高温環境下に打いて, 張 力・搬送速度の切替から安定走行に至るまでの過渡的な 張力变化をリアルタイムに検出可能にすることにより，

フィルムの挙動に応じた走行制御の可能性が示された。

張力検出部のロールシャフト内蔵による小型化, 高温・真 空環境に扔ける高精度でリアルタイムな張力検出・制御な ぞ，ロールッーロールスパッタシステムに対するセンサロー ルの高い適用性が見出された。

\section{謝辞}

ロールツーロールスパッタ装置の使用をご快諾頂き，実験 の際に様々なご指導・ご協力を頂きました, 三容真空工業株 式会社代表取締役社長伊達剣治氏, 技術部課長黒木宏芳氏に 深く感謝致します.

\section{〔文献〕}

1) H. Nakayama, M. Nakayama, S. Ogawa, et al.: The Latest Element Technology of Film Based Electronic (CMC Publishing, Tokyo, 2008) p. 117.

2) H. Tamagaki, T. Segawa and N. Ohba: R\&D Kobe Steel Engineering Reports, 58 (2008) 42.

3) S. Kondo, H. Tamaki, H. Takenaka, M. Takemura and S. Ogawa: J. Vac. Soc. Jpn., 53 (2010) 364. 